\title{
Introduction to Fortress Europe: Media, Migration and Borders
}

\author{
SARA MARINO, King's College London \\ SIMON DAWES, Université Paul Valéry, Montpellier
}

This issue was commissioned in response to the unfolding refugee (or 'migrant') 'crisis', and in particular to the mediated representation of the 'refugee', 'migrant' or 'asylum seeker' and the increasing securitization of Europe's borders.

In recent years, different metaphors have been created in order to describe the hardening of Europe's external borders against undocumented and unwanted migration. 'The Wall', 'the gated continent', 'the gold curtain' and 'the leviathan' are all catchy metaphors that have been used to describe what is, in fact, a common determination to limit and ultimately to stop the mobility of certain categories of people. More recently, the 'Fortress Europe' metaphor which originates in the military context of the Second World War - has been frequently used (and abused) to identify Europe's new repressive measures to protect the external borders of the Union from unwanted dangers as well as security considerations. Using the words of journalist Matthew Carr, "for more than two decades now, the European Union has been conducting the most extensive, sophisticated and far-reaching border enforcement programme in history, largely in an attempt to prevent 'illegal' immigration - a category that generally refers to undocumented 'economic migrants' and refugees from poor countries and the Third World" (Carr 2012). Borders have largely functioned as a 'carrot-and-stick' approach, seeking to preserve and maintain an efficient system on internal borders for those entitled to stay within the EU market, while preventing unwanted and unwelcomed people from entering. Far from being a mere component of international stability and political cooperation, borders have in fact reiterated and justified the 'us vs. them' and invasion narratives that still challenge Europe's relationship with its cultural and social diversity.

In particular, the rise of global terrorism and organised crime, which many have interpreted as the dark side of globalization (Heine \& Thakur 2011), have contributed to the development of a generalised sentiment of fear that has shifted the debate around migration from control to security. According to Buonfino, and particularly after 11 September 2001, immigration began to symbolise all the dangers any nation might ever experience: the scapegoat for all kinds of European feelings of instability; the fear of losing political, social and cultural cohesion; and perhaps more importantly the contamination of Europe's national identity (Buonfino 2004). This, coupled with the rise of populist rhetoric in public discourse that focuses on the crime, violence and danger posed by migration, rather than on migration itself, has increased social insecurity and anxiety amongst the states and their citizens. In the name of security, hundreds of millions of euros have been spent on the reinforcement of border controls; the need to secure land, sea and air borders with fences, border guards, border agencies, databases and surveillance technologies have contributed to the construction, and reinforcement, of Fortress Europe. 
The complexity of Fortress Europe is something that this issue has recognised as particularly compelling and in need of further investigation. First, the term refers to a global displacement crisis, with more people than ever before fleeing conflict, violence and violations of basic human rights, particularly from the Middle East. Second, it calls into question the crisis of EU migration management and the supposed failure of the European project. The chaotic and often tragic consequences of Europe's 'managed migration' policies in Lampedusa in 2013 and more recently in Greece and along the West Balkan route - just to name some of the case studies analysed by our contributors - have called into question the effectiveness of the European model and its human and political costs.

On the one hand, the human costs of Fortress Europe are now alarmingly evident in the number of deportations, immigration raids, identity checks and police harassment. Among others, Thomas Nail has written about the migrant as the political figure of our time (Nail 2015), while Giorgio Agamben has reflected on how refugees and refugee camps have become emblematic paradigms of the space of modernity (Agamben 1998). Silenced, excluded from the political space of Europe both symbolically and politically, reduced to naked (or bare) lives 'in-waiting', refugees represent the emblematic figure of our time, entering a space where forms of legal and political de-legitimization (read: citizenship rights) concur to the suspension and denial of basic human rights (Frost 2013). Similarly, artist and film-maker Ursula Biemann has defined refugee camps as zones of exception outside national boundaries, administratively and judicially separate from the political/legitimate space. The camp, therefore, is not an historical anomaly; rather, it is the very symbol and symptom of "the new biopolitical nomos of the planet" (Agamben 2000).

On the other hand, Europe's hardened borders call into question the nation states' inability to respond to the crisis in a coherent and structural manner. As Carr repeatedly argues, from both a moral and humanitarian perspective, Europe's borders constitute a monumental failure. First, because its migration policies have not stopped migrants from trying to reach Europe; on the contrary, they have made their journey even more dangerous. Second, because the EU's clear failure to show unity and to provide a coherent international framework over the refugee humanitarian crisis can be seen as the failure of the union as a political concept.

While member states dispute over who is doing what, refugees and migrants die. More than three thousand people died or went missing in 2015 while trying to reach Europe in search of a better life. According to the UN Refugee Agency, the first months of 2016 witnessed 728 dead/missing persons. As Malik quite poignantly says, "Fortress Europe has created not only a physical barrier around the continent but an emotional one, too, around Europe's sense of humanity" (Malik 2013). For David Morley (in this issue), the EU's inability to accommodate the figure of the migrant represents a crisis for European identity. For Nail (see Wolters 2015), it is symptomatic of a problem at the heart of liberal democracy and the international and infra-national nation-state system - the incommensurability of the value of universal equality with the limits of territorial, political, legal, and economic borders.

A lesson has to be learned. The human costs of Europe's fears of migrant invasion are only a part of the problem. More generally, it is time to change the European discourse towards new forms of legal and ethical hospitality. 


\section{The articles in the issue}

This issue presents a range of case studies of European media coverage of the 'refugee crisis', including analyses of coverage in the British press (Ibrahim \& Howarth, Silveira), on Italian newspaper websites (Vieira), on social media platforms (Alinejad, Harrison), and through geospatial technologies (Synenko), as well as in German stand-up comedy (Herbers). The right-wing and left-wing mainstream media are compared and contrasted (Silveira), and antiausterity, pro-refugee social media content (Alinejad) is analysed alongside a neo-fascist group's use of Google Maps (Synenko). Both the Mediterranean Sea (Vieira) and the 'Jungles' in Calais (Ibrahim \& Howarth) are examined as particular sites of mobility and liminality. Several of the articles in the issue (Marino, Harrison, Ibrahim \& Howarth) draw extensively on Agamben's theories of 'bare life' and 'states of exception' to address the experience and status of migrants/refugees at the borders of Fortress Europe.

The issue begins with Sara Marino's article 'What Are We Going to Do about Them? The Centrality of Borders in Fortress Europe', which discusses the centrality of borders, bodies and violence in the context of Europe's increasing securitization. By conceptualising borders as institutions of power, as processes of identity formation, and as performances, and drawing in particular on the work of Agamben and Vaughan-Williams, Marino argues that borders embody a permanent state of exception where contingent and politically charged meanings of identity and subjectivity dominate the exercise of sovereign power. Refugees caught in this state of exception thus become bare lives and objects of violence and arbitrary acts of power.

The media have tended to portray migrants and refugees as either objects of fear or pity, and Alexander Callum Harrison focuses on these two competing media narratives in his article, 'Mediations of 'the Refugee Crisis': The (Ir)reconciliation of Ideological Contradictions in Fortress Europe'. Focusing in turn on the politics of fearism behind the representation of refugees as hate figures, and the counter-narrative that encourages sympathy with them as victims, Harrison highlights how the irreconcilability of these two discourses has resulted in the trivialisation of debate to a balance between national security and humanitarian issues, and an abundance of doctored images and misinformation on social media.

In tandem with the increase, particularly since the summer of 2015, in media attention given to refugees trying to reach Europe has been an even greater increase in visual depictions of refugees and refugee camps. In their article, 'Imaging the Jungles of Calais: Media Visuality and the Refugee Camp', Yasmin Ibrahim and Anita Howarth examine this increase in the visualisation of the Calais 'Jungle' camps in the British press, arguing that this 'visual turn' reinscribes the refugee as a political by-product of border politics, and accentuates the refugee camp as a violent and dissonant space in 'civilised' Europe.

While photographs of refugees and refugee camps make up a substantial part of this visualisation, so too do maps showing the routes taken into Europe, as well as the final destinations of asylum seekers. In his article, 'The Geospatial Rhetoric of Asylum: Mapping Migration in Fortress Europe', Joshua Synenko considers the case of the neo-fascist group, Der III Weg, and their instrumentalisation of Google Maps to highlight the locations of refugee asylum houses throughout Germany. Examining the group's tactical use of geospatial technologies to further their campaign of intimidation and violence, and drawing on literature on the relation between maps, power and identity, Synenko argues that this particular map, 
and its use in Der III Weg's publicity campaigns, raises questions about the modes of subjectivity and the tactics of public engagement facilitated by such technologies.

In her article, 'The Construction of the Mediterranean Refugee Problem from the Italian Digital Press (2013-2015): Emergencies in a Territory of Mobility', Inês Vieira focuses on the Mediterranean Sea itself as a site of mobility, and on the media representation of the 'crisis' from a constructivist perspective. Analysing two particular Italian news websites, Vieira details the various frames used to discuss Mediterranean refugees to show how press coverage has evolved over the previous 3 years.

In 'The Representation of (Illegal) Migrants in The British News', Carolina Silveira uses multimodal critical discourse analysis (MCDA) to examine articles from The Guardian and the Daily Mail. Deconstructing two ideologically dissimilar news articles to reveal the manner in which they can both contribute to the negative construction of refugees and migrants arriving in Europe, Silveira demonstrates how both news articles contribute to a similar discourse that 'others' the refugee and presents the UK as being under threat.

Despite the dominance of the 'Fortress Europe' discourse, however, Martin R. Herbers suggests one way in which it can be subverted. In 'StandUpMigranten: The Role of Television Comedy for the Discourse on Migration in Germany', Herbers analyses the ways in which comedy, as a specific type of rhetoric, can produce a counter-rhetoric, especially if used by migrants as the dominated group themselves, thus giving a voice to groups of people who are otherwise silenced, and 'opening the gates of 'Fortress Europe' one joke at a time'.

In the final article of the issue, "Europe Says OXI: "Online Camaraderie" and European Crisis', Donya Alinejad draws connections between the economic and refugee 'crises' in Europe at the moment. Focusing on the Facebook page, Europe Says OXI, and the incorporation of the refugee issue into support for the Greek anti-austerity movement in the content posted, Alinejad uses this case study to explore the relationship between collectivity, connectivity and what she calls 'online camaraderie'.

The issue concludes with the editors' interview with David Morley, 'Media, Migration and the Borders of Fortress Europe'. Having written extensively on how audiences interpret media texts differently, about emotional disconnectedness, and about mobility, geography and 'territory', Morley looks back on several of his key texts to address the contemporary European refugee 'crisis', the representation of the 'migrant' and the increasing securitization of Europe's borders. Discussing the links between geopolitics and communications, between the virtual and material realms, and between contemporary debates and the historical decline of Europe on the world stage, Morley argues that the current refugee crisis is also a crisis of Europe's political identity.

We hope the issue provides a rich variety of the research currently being undertaken by emerging scholars into the relation between media, migration and borders in the context of the so-called refugee 'crisis', as well as a substantial scholarly critique of the contemporary fortressing of Europe. 


\section{References}

Agamben, G. (1998) Homo Sacer, Stanford, CA: Stanford University Press.

Agamben, G. (2000) Means without Ends: Notes on Politics, Minneapolis: University of Minnesota Press, p. 45.

Buonfino, A. (2004) 'Between Unity and Plurality: the Politicization and Securitization of the Discourse of Immigration in Europe', New Political Science 26(1), 23-49.

Carr, M. (2012) 'The Trouble with Fortress Europe', [online], 21 November. Available at https://www.opendemocracy.net/matthew-carr/trouble-with-fortress-europe . accessed 15 April 2016.

Frost, T. (2013) Giorgio Agamben. Legal, Political and Philosophical Perspectives, London: Routledge.

Heine, J. and Thakur, R. (2011) The Dark Side of Globalisation, United Nations University Press.

Malik, K. (2013) 'In defence of cultural diversity', [online], 18 December. Available at http://www.eurozine.com/articles/2013-12-18-malik-en.html. Accessed_15 April 2016.

Nail, T.(2015) The Figure of the Migrant, Stanford, CA: Stanford University Press.

Wolters, E. (2015) 'The Figure of the Migrant, an Interview with Thomas Nail'. Available at: http://www.critical-theory.com/the-figure-of-the-migrant-an-interview-with-thomas-nail/

Sara Marino is a Teaching Fellow in Digital Culture at the Department of Digital Humanities at King's College London. She holds a PhD in Communication Science from the University of Urbino (Italy), where she worked on digital media and diaspora. Her doctoral dissertation, "Online and offline diasporic communities. Italians in London", examined the use and impact of Internet technology on immigrants' identity, sense of community and ideas of belonging.

She previously worked as a Visiting Lecturer at the University of Westminster, and as Associate Lecturer at Central Saint Martins - University of the Arts.

Her main research focuses on the social understanding and analysis of digital diasporas from a political economy perspective that seeks to explore how the socio-economic European scenario has affected intra-European migration. More recently, she became interested in the study of borders and transit zones, especially in relation to the refugee crisis and to the idea of Fortress Europe.

Email: sara.marino@kcl.ac.uk 
Simon Dawes is the editor of Networking Knowledge - the Journal of the MeCCSA PGN, editorial projects \& website manager of Theory, Culture \& Society and Body \& Society, and editor of the media \& communication studies section of the Open Library of Humanities. He teaches at Université Paul Valéry, Montpellier, France.

His research revolves around issues of media theory, history and regulation. Last year he coedited (with Nour Shreim) a special issue on 'Mediatizing Gaza' (2015). Currently, he is writing a monograph based on his $\mathrm{PhD}$ thesis, Broadcasting and the Public-Private Dichotomy (forthcoming, Palgrave Macmillan).

Email: simondawes0@gmail.com 